\title{
Landslide development at the shores of a dam reservoir (Włocławek, Poland), based on 40 years of research
}

\author{
Halina Kaczmarek $^{1} \cdot$ Sebastian Tyszkowski $^{1} \cdot$ Mieczysław Banach $^{2}$
}

Received: 30 May 2014/Accepted: 27 April 2015/Published online: 10 May 2015

(C) The Author(s) 2015. This article is published with open access at Springerlink.com

\begin{abstract}
This article presents results of our 40-year research on dynamics of a deep rotational landslide developed in clay deposits. The landslide is located in a lowland, within the shoreline of Włocławek Reservoir, with little water level variation, in Dobrzyń on the Vistula (northern Poland). It is an old landslide, which was active also before the construction of the reservoir. Our research was initiated in 1970, i.e. when the river Vistula was dammed there. Currently the landslide covers about $20,000 \mathrm{~m}^{2}$ and has a volume of about $160,000 \mathrm{~m}^{3}$. During the 40 years, 3 periods of increased landslide activity were observed. The first, conspicuously, nearly $40 \%$ increase in the rate of movements within the Central Landslide was initiated in the early 1970s and lasted till the early 1980s. It coincided with the initial filling of the reservoir and the first years of exploitation of Włocławek Reservoir. The increase in landslide dynamics was a direct effect of hydrological and morphological changes associated with the damming of the river. The next 2 periods of increased landslide activity occurred: in 2001/2002 and 2010/2011. The latter was the most spectacular displacement within the Central Landslide. It was recorded between December 2010 and February 2011, and reached 10.0-19.4 m, after unusually long-lasting, heavy rainfall in the summer and autumn of 2010, followed by snowmelt and unfavourable changes in air temperature. Since March 2011, no movements within the landslide have been recorded.
\end{abstract}

Halina Kaczmarek

halina@geopan.torun.pl

1 Department of Environmental Resources and Geohazards, Institute of Geography and Spatial Organization, Polish Science Academy, Kopernika 19, 87-100 Toruń, Poland

2 Institute of Geography and Regional Studies, Pomeranian University in Słupsk, Partyzantów 27, 76-200 Słupsk, Poland
Keywords Landslide acceleration · Geohazards · Rainfall · Włocławek reservoir - Mass movement monitoring · Water level

\section{Introduction}

Landslides located on slopes of artificial water bodies are forms, developed in the environment disturbed by human activity. They pose serious, permanent threat to humans and to infrastructure located around reservoirs. Creation and exploitation of each reservoir results in modification of initial factors and appearance of new factors that may activate landslides. Beside natural factors, such as geological structure, hydrometeorological conditions or earthquakes, the landslides are additionally affected by anthropogenic factors, associated with the filling or operation of the reservoir, e.g. morphology of the flooded slope, changing in the course of shoreline (Banach 1985, 2004; Ovchinnikov et al. 1999; Levkevic and Lopuch 2003; Loo 2006; Kaczmarek and Tyszkowski 2009; Kaczmarek 2010a, b) or considerable rapid reduction of water level (Jones et al. 1961; Rybáŕ 1974; Schuster 1979; Vichas et al. 2001; Schuster and Wieczorek 2002; Spanila et al. 2002; Deying et al. 2010; Zhang et al. 2010; Pinyol et al. 2012), as such sudden changes affect hydrostatic groundwater pressure in the slope. These factors often coincide, leading to a sudden, drastic decrease in slope stability, increasing the activity of landslide processes (He et al. 2008). The rise in pore water pressure on the slope results in changes in geotechnical parameters of the soil, mostly reducing its cohesion and shear strength and increasing its weight and bulk density.

The high diversity of factors affecting landslides on slopes of water bodies and their interactions make it necessary to identify the causes and to assess the risk of 
landslide activation for each reservoir individually, both during its initial filling and during its later exploitation.

Landslides on slopes of artificial water bodies were of little interest to scientists till 1963, when a disastrous landslide took place near the Vajont Dam (north-eastern Alps, Italy). Only 3 years after creation of the reservoir, a huge, renewed landslide of about 270 million $\mathrm{m}^{3}$ collapsed from Monte Toc. The landslide completely filled up the reservoir and caused a water wave to overtop the 262-metre-high dam by about $100 \mathrm{~m}$. The wave killed about 1900 people, although the dam was not destroyed (Alonso et al. 2010; Genevois and Ghirotti 2005). The landslide took just 20-25 s, at a rate of $20-25 \mathrm{~m} / \mathrm{s}$ h (Panizzo et al. 2005).

Currently it is common knowledge that filling and exploitation of dam reservoirs has a negative effect on the stability of the slopes surrounding them, and thus leads to intensification of landslide activity (Banach 1985; Deng et al. 2005; Xue et al. 2009). As a result of changes associated with the creation of reservoirs, pre-existent landslides are activated and new ones develop in the immediate vicinity of the created reservoirs, especially in the first few years after their filling (Jones et al. 1961; Trzhtsinsky and Demianovic 1977; Banach 1985; Du et al. 1996; Trzhinski et al. 1977; Wang et al. 2004, 2005; Fawu et al. 2006; Loo 2006). Riemer (1995), who analysed 60 publications concerning landslides in reservoirs, found that $85 \%$ of landslides associated with reservoirs are initiated at the stage of their creation and filling or in the first 2 years after their filling. According to a report of the International Commission on Large Dams (Reservoir landslides 2002), $75 \%$ of the landslides that developed at the shores of reservoirs are old, reactivated forms. Increased activity of landslides located at the shoreline is often observed whenever the reservoir is filled with water, but the movements are pulsating, and the activation phases are separated by stabilisation phases (Banach 1985; Nazarov 2008).

In this study we investigate landslide dynamics and demonstrate causes of several cases of higher-than-average activation of an old, deep landslide, developed in clay deposits, which as a result of river damming was activated and now its body is at the shoreline of the reservoir (Central Landslide in Dobrzyń on the Vistula, at the shore of Włocławek Reservoir, northern Poland) (Fig. 1), in relation to 40-year own research on this landform (Banach 1994, 2006).

\section{Study area}

Włocławek Reservoir (or Lake Włocławskie, in Polish known as Zbiornik Włocławski, Zbiornik Włocławek, Jezioro Włocławskie or Zalew Włocławski), with the slope where the Central Landslide has developed, is located in the upper section of the Vistula River in northern Poland
(Central Europe) (Fig. 1). The area is completely covered by Quaternary glacial, glaciofluvial, and fluvial deposits, forming high plateaus or river terraces, locally with dunes. The Quaternary deposits are 20-50 m thick. They are underlain by fine sand, silt, and clay deposits dating back to the Pliocene or Miocene. Altitude is about $95-100 \mathrm{~m}$ in the plateau and 57-60 $\mathrm{m}$ in the Vistula valley, which dissects it. The climate is temperate, with annual precipitation of 450-550 mm (320-350 $\mathrm{mm}$ in May-October). Annual mean air temperature is $8-9{ }^{\circ} \mathrm{C}$.

Northern Poland, because of its relief and geological structure, generally has relatively low landslide activity. Apart from the Baltic coast, infrequent landslides are limited nearly exclusively to slopes of large river valleys, especially of the Vistula (Tyszkowski 2012). These are mostly small, shallow rotational landslides and forms developed in the process of downhill creep. A peculiar area, characterised by exceptionally high activity of mass movements and their diversity is the shoreline of Włocławek Reservoir.

Włocławek Reservoir was created in 1969. Among Polish reservoirs it ranks first in terms of area $\left(70 \mathrm{~km}^{2}\right)$ and second in terms of volume $\left(376 \mathrm{mln}^{3}\right.$ ) (Gierszewski and Szmańda 2010). Its depth is on average $5.5 \mathrm{~m}$ (maximum $13 \mathrm{~m}$ ), length $55 \mathrm{~km}$, and width $2 \mathrm{~km}$. It is a typical lowland reservoir, of the valley type, with little water level variation (not exceeding $1 \mathrm{~m}$ annually). Mean daily variation in water level is up to $0.2 \mathrm{~m}$ (Banach 2004). The reservoir is latitudinally oriented. In relation to tectonics, it is located at an edge of the Zechstein-Mesozoic Pomeranian-Kuyavian anticline, covered by Mesozoic and Kenozoic deposits. The slow uplifting of the anticline, also in the form of neotectonics, results in continuous sliding of the valley in the north-eastern direction (Ostaficzuk 1998). The area is currently classified as aseismic. Due to such a location, the right and left banks of the reservoir differ in geological structure and morphology (Fig. 1). The left bank is low, developed in Pleistocene and Holocene river terraces of the Vistula. It consists of Pleistocene glacial and late glacial sands and Holocene aeolian deposits. The right bank of the reservoir is a high slope of Dobrzyń Plateau (Wysoczyzna Dobrzyńska) and Płock Plateau (Wysoczyzna Płocka). The slope is about $40 \mathrm{~m}$ high and slope angle ranges from $10^{\circ}$ to $50^{\circ}$. It is composed of Neogene and Pliocene clays and sands covered by Pleistocene glacial and fluvio-glacial deposits (Banach 1977). Even before construction of Włocławek Reservoir, landslide activity was recorded on the slope. In the first years of exploitation of the reservoir, nearly $32 \%$ of the total length of its right bank, i.e. $14.5 \mathrm{~km}$, were involved in mass movements (Banach and Spanila 2000). Currently, after 40 years of exploitation of the reservoir, erosion at the base of coastal slopes is lower, accompanied by gradual reduction of mass 


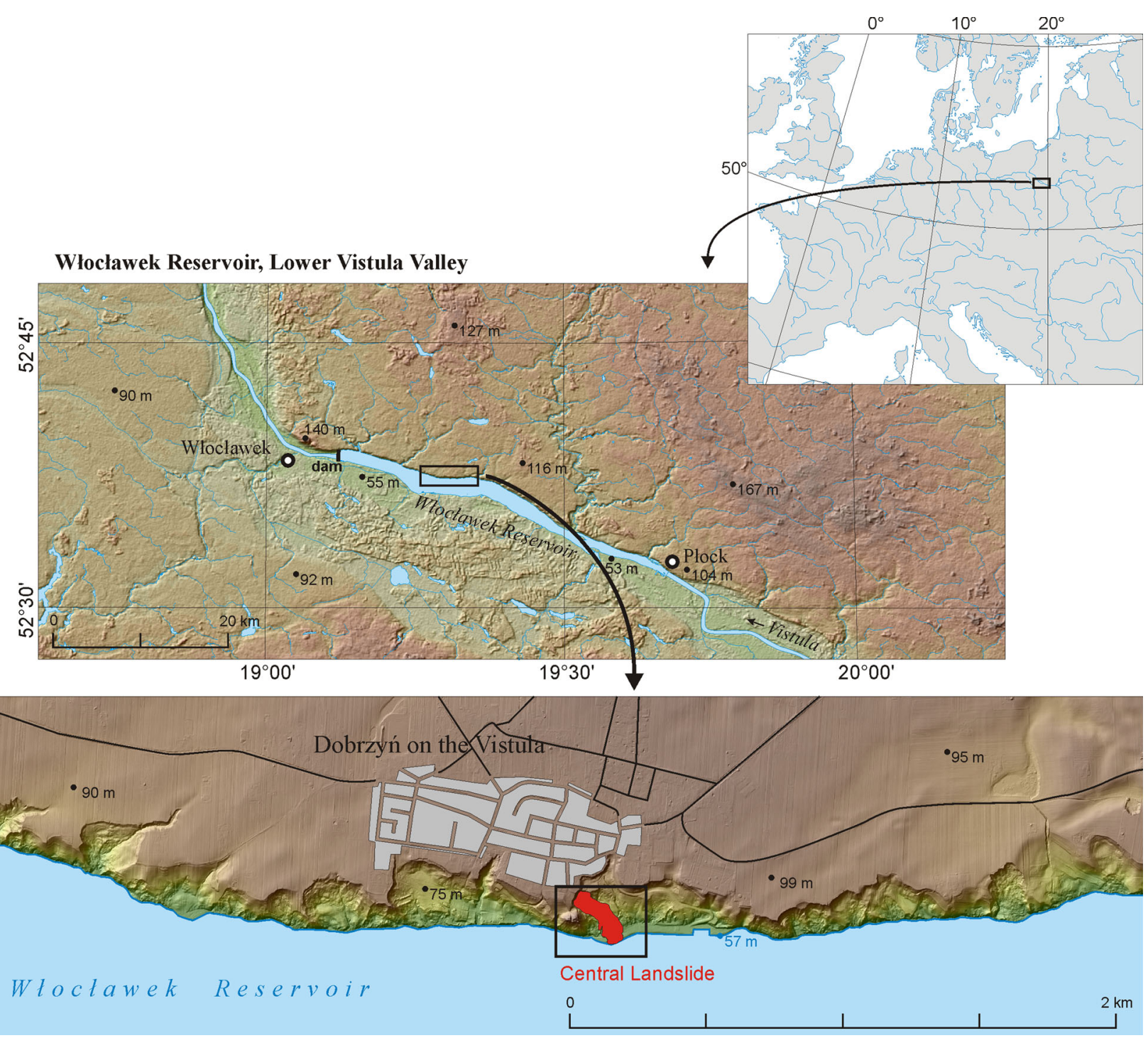

Fig. 1 Location of the study site

movements. One of the largest active landslides on Włocławek Reservoir is the Central Landslide in Dobrzyń on the Vistula, developed within its right bank (Fig. 1). This form, active also in historical times, markedly reacted to changes caused by construction of the reservoir. In the course of landslide evolution in the last few decades, many houses and other buildings were destroyed (Fig. 2). Thanks to long-term research and detailed monitoring, it is one of the best-studied valley landslides in the Polish lowland.

\section{Methods}

Research on the Central Landslide was initiated in 1969, i.e. when Włocławek Reservoir was created. At that time, on the active landslide, a network of 15 geodetic control points was established. For initial land surveying, optical theodolites were used. Since 2010, we have applied a total station (Leica TC 500) and GPS receiver (Trimble R4). Displacements were measured to nearest $1 \mathrm{~cm}$. Measurements were made there with varying frequency, initially several times a year (1970-1974), later every 2-3 years (1974-1986). Since April 2010, frequency of measurements was increased again. Additional, new control points were established then, so that their total number was 30, but in the course of landslide activity, many of them were destroyed. The ones that could be monitored for a long time are presented in Fig. 2. Their displacement reflects the landslide dynamics from 1970 to 2011 .

To reconstruct the morphology and dynamics of the landslide in the period preceding the construction of Włocławek Reservoir, we used aerial photographs taken in 1959 and 1970 at a scale of 1:10,000. 
Fig. 2 a Map of the Central Landslide with marked control points (benchmarks) and vectors of movements between 1970 and 2011. Digital terrain model based on aerial LiDAR.

b Profile across the landslide in 2008 and 2012
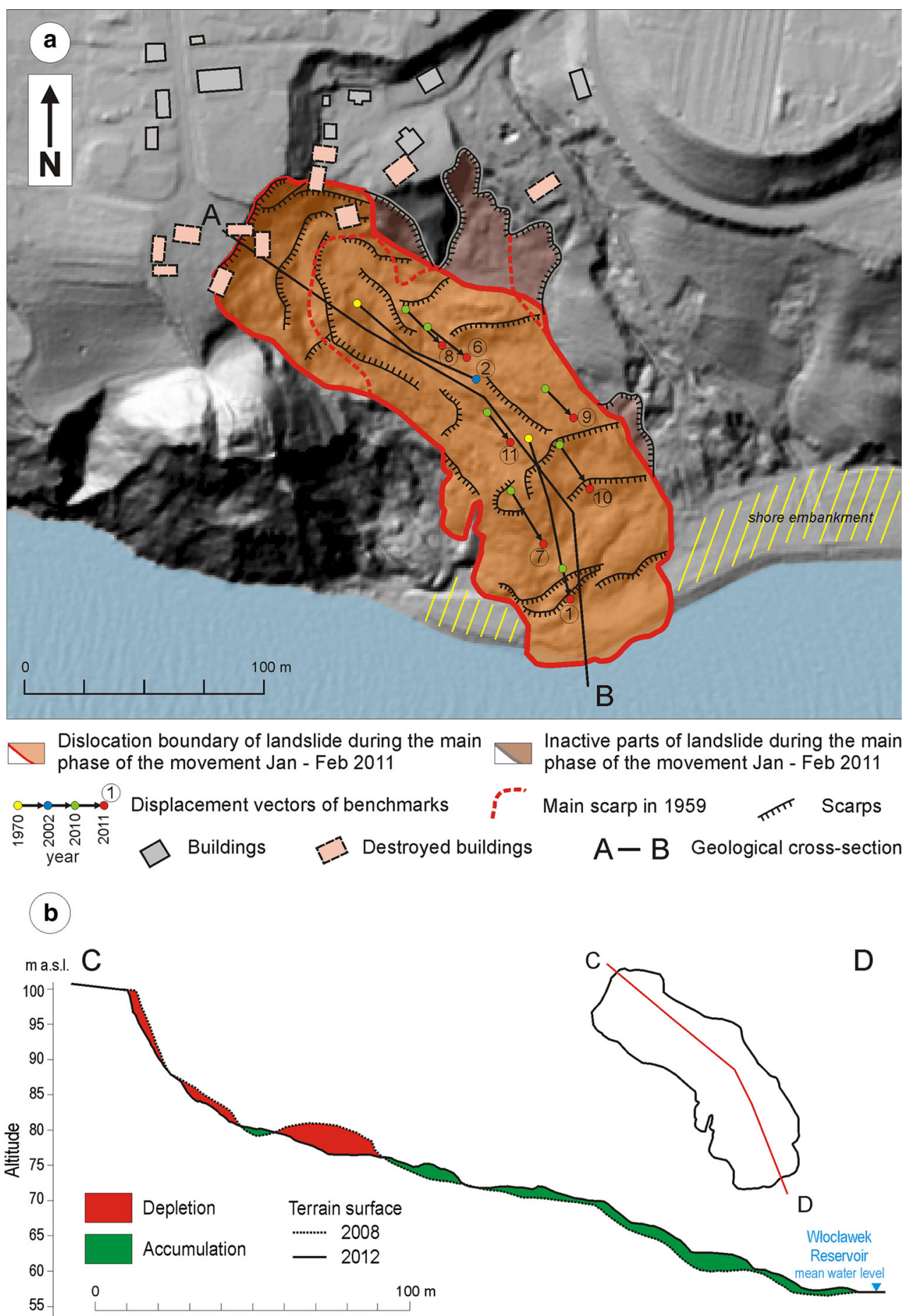

During geomorphological mapping as well as when marking of the form outline and in other field research since 2010, differential GPS receiver has been used.

Weather data come from the Station of the Institute of Geography of the Polish Academy of Sciences in Dobiegniewo, located on the opposite bank of Włocławek Reservoir, $2 \mathrm{~km}$ away from the study site. Moreover, we analysed data on water level in Włocławek Reservoir since its creation.

\section{Geological and morphological conditions of the Central Landslide}

The edges of the Vistula valley near Dobrzyn consist of Miocene, Pliocene, and Quaternary deposits. Miocene deposits, from 10 up to $120 \mathrm{~m}$ in thickness, are represented by clays, clay silts, sands, and several layers of brown coal (lignite). Pliocene deposits are dominated by clays, while 
Quaternary deposits are composed of 2 layers of till, about $15-30 \mathrm{~m}$ thick, separated by a 3-m layer of sand with gravel, overlying a moraine lag deposits consisting mainly of pebbles or boulders.

The landslide is $220 \mathrm{~m}$ long and $60-90 \mathrm{~m}$ wide. It covers an area of about $20,000 \mathrm{~m}^{2}$ and has a volume of about $160,000 \mathrm{~m}^{3}$ (Fig. 2). The main scarp reaches an altitude of $99 \mathrm{~m}$ a.s.l., while the toe is partly below the water level in the reservoir and the shoreline is at $57 \mathrm{~m}$ a.s.l. Thus the difference in altitude is $42 \mathrm{~m}$. Mean slope angle is $13^{\circ}$, and it is a rotational landslide. The upper part of the landslide crown is located in Quaternary deposits (2 layers of glacial till, separated by sandy deposits) about $20 \mathrm{~m}$ thick, overlying Pliocene clays (Fig. 3). Selected geotechnical parameters of the soils are presented in Fig. 4, based on the data of Kuszyk et al. (2012).

It is a deep rotational semi-circular landslide. This form develops as a result of retrogressive erosion (headward erosion). In the lower part of the landslide, in the surface layer (2-3 m thick), slow earthflow is observed. With the use of inclinometers in the late 1970s (Madej 1981), shear planes were identified at the depth of 7,9 , and $16 \mathrm{~m}$. Because of the great dynamics of the landslide, inclinometric boreholes were destroyed and were not restored. Research conducted at the end of 2012 by Kuszyk et al. (2012) (e.g. geological drillings and cone penetrometer test) indicate that there are many shear planes (Fig. 3).

Landslide borders are very conspicuous. The main scarp is $8-12 \mathrm{~cm}$ high. In the landslide morphology, secondary scarps are clearly visible, $2-4 \mathrm{~m}$ high. All the displaced material is dissected by numerous cracks, up to $1.5 \mathrm{~m}$ deep and $0.5 \mathrm{~m}$ wide. Differences in elevation within the landslide are up to 2-3 m, and are the largest in its central part. Within the landslide, there are many shallow depressions $(0.5-1.0 \mathrm{~m}$ deep), filled with water periodically or all the time.

The Central Landslide is an old landslide, which was active long before the creation of Włocławek Reservoir

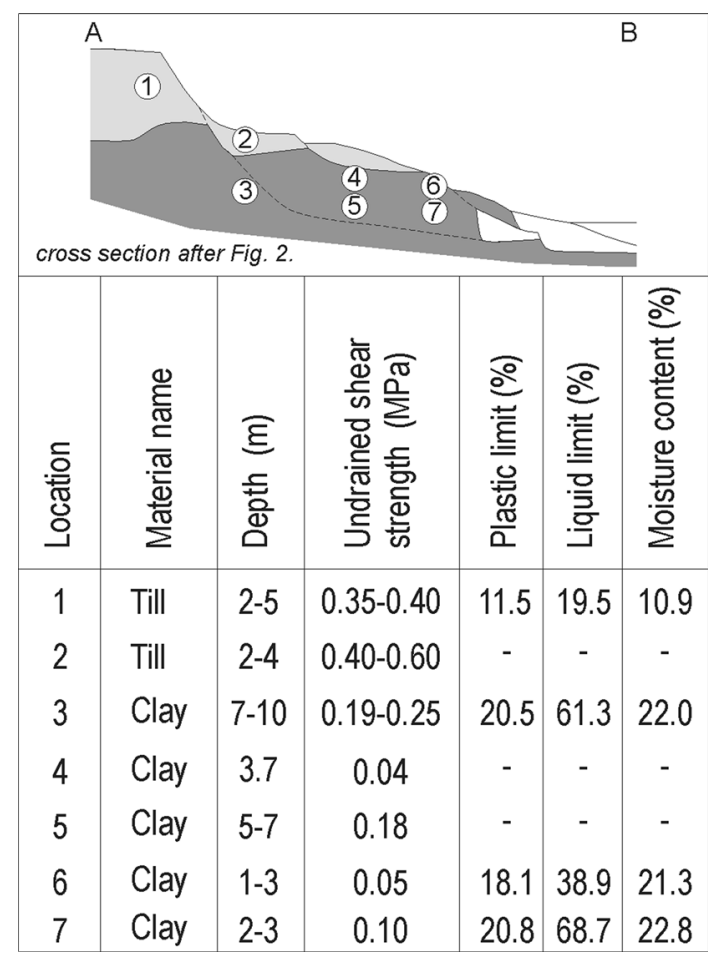

Fig. 4 Selected geotechnical parameters of the soils

(Banach 1977). The local geological stratification is of major importance for its development (Banach 1977). Nearly the whole length of the right bank, where the study site is located, contains glaciotectonic folded Neogene deposits, covered by horizontal Quaternary sediments (Ostaficzuk 1998). The amplitude of folds of Neogene deposits varies from 40 to $90 \mathrm{~m}$, and they are oriented in the NW-SE direction, nearly perpendicular to the axis of the reservoir. Narrow anticlines, mostly composed of Miocene deposits, are partly exposed above the water level, up to a height of $25 \mathrm{~m}$. The elevated parts are separated by deep and much wider synclines, falling much below the

Fig. 3 Geological cross section of the Central Landslide

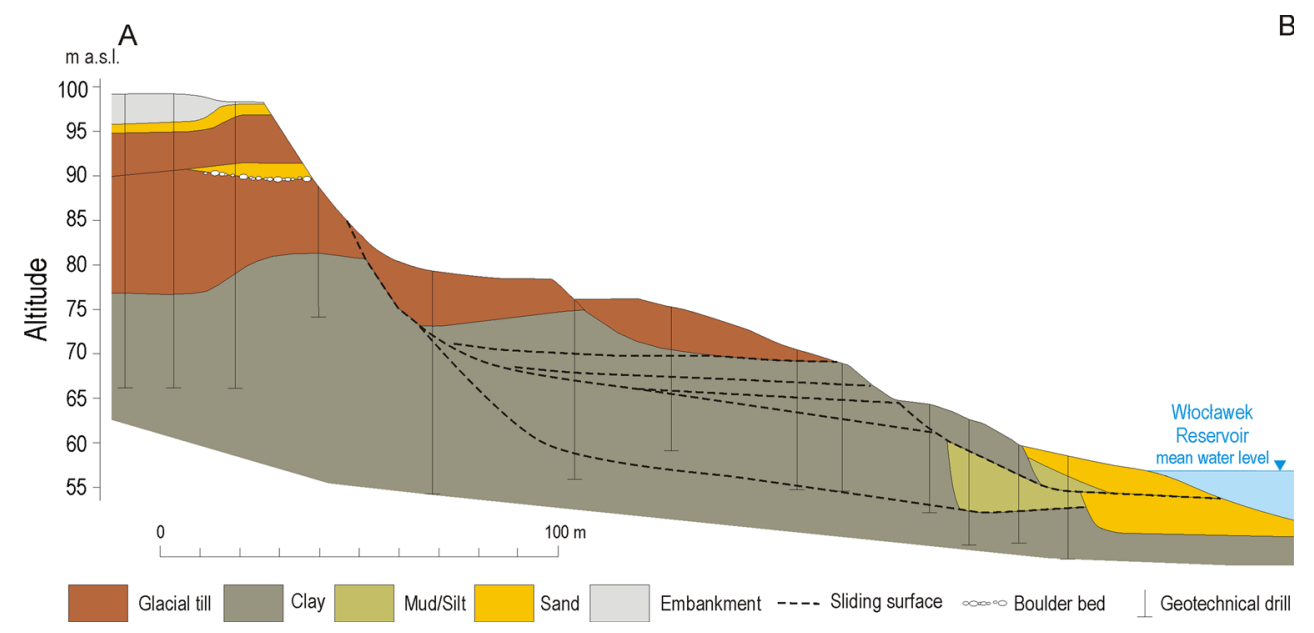


local base level of erosion of the Vistula. The Pliocene synclines contain 1-2 aquifers. In the NW-SE axes of these forms, in the places where Pliocene clays are located above the water level of the reservoir, various landslide forms are developed. Transformed glaciotectonic clays are characterised by the presence of cracks, fissures, and slickensides, which lower their shear strength (Meissner 1970; Wysokiński 2006). An important role in the development of the Central Landslide, before creation of Włocławek Reservoir, was also played by erosive activity of the Vistula, whose main current, when water level was high, cut the edge of the Dobrzyń Plateau in this area.

Because of the great variation and displacements of geological strata within the landslide, it is now impossible to distinguish well-defined aquifers, as waters from stratigraphically different layers are not separated. Moreover, water circulation is facilitated by the network of fissures in Neogene deposits.

\section{Change in conditions of development of the Central Landslide as a result of creation of Włocławek Reservoir}

Creation of Włocławek Reservoir caused changes in morphodynamic processes on the slope of the Vistula valley. The short-term occasional bank erosion by the river (when water level was high) was replaced by long-term (9-10 months a year) shoreline erosion caused by wind waves. Due to the dam, river width (originally 800-950 m) was doubled (now 1800-1950 m). The lower part (15-50 m wide) of the slope of the Vistula valley, with a large part of landslide colluvium, was covered with water, also within the Central Landslide. The flooded part of the slope in successive years was intensively washed out by waves.

As a result of creation of Włocławek Reservoir, also hydrogeological conditions were changed, affecting the development of the Central Landslide. The dam on the Vistula was built in 1969, and a year later the reservoir was filled to the established geodetic control points. In the Dobrzyń region, water level in the reservoir was raised about $8 \mathrm{~m}$ as compared to mean water level before flooding, and $2.9 \mathrm{~m}$ above the highest water levels recorded earlier. Annual amplitude of water level fluctuations were reduced 3-fold, from $6 \mathrm{~m}$ to a maximum of $2 \mathrm{~m}$ (Glazik 1978).

Damming of the Vistula caused also changes in groundwater circulation at the edges of the plateau. In a belt $200-300 \mathrm{~m}$ wide, hydraulic gradient (I) decreased from $0.016-0.032$ to $0.004-0.016$ after dam construction, and the amplitude of changes in groundwater level was reduced 6-8-fold (Banach 1977, 1985), as now it does not exceed 0.5-0.6 m. In looser and more permeable Miocene deposits, where the water table was stabilised about a dozen weeks after the end of impoundment of the Vistula, the hydraulic gradient decreased nearly 4-fold. In Pliocene deposits, where as late as 3 years after the impoundment the water table still showed an increasing trend, hydraulic gradient decreased 2-fold. As a result of the changes, the dynamic pressure of groundwater decreased. Within the Central Landslide, damming of the Vistula caused permanent flooding of the older shear planes, developed in Pliocene clays.

\section{Development of the Central Landslide}

The study site is an old active landslide, reported in the literature since the early 20th century (Gelinek 1929). The mean rate of its movement in the period preceding the construction of Włocławek Reservoir (1959-1970) was estimated at $2.6 \mathrm{~m} / \mathrm{year}$ on the basis of photogrammetric measurements.

As a result of changes associated with the construction of Włocławek Reservoir, the activity of pre-existent landslides increased and new landslides appeared along the whole right bank of the reservoir (Banach and Spanila 2000). The rate of movement of the Central Landslide in the first 4 years after creation of the reservoir (1971-1974) increased to $3.6 \mathrm{~m} / \mathrm{year}$, i.e. was $38 \%$ higher than in 1959-1970 (Banach 1977). In the landslide cross section, the rate of colluvium movement clearly varied depending on the distance from the edge of the main scarp: $1.8 \mathrm{~m}$ in the upper part, $2.5 \mathrm{~m}$ in the middle part, and $3.6 \mathrm{~m}$ in the lower part of the landslide. Moreover, in that period, the rate of colluvium movement clearly varied also seasonally. Movements in the cold half-year (November-April) were 3-6-fold larger than movements in the warm half-year (May-October). A similar distribution of the rate of colluvium movement was observed till the early 1980s. On average in 1970-1984 it annually reached $1.4 \mathrm{~m}$ in the upper part, $2.4 \mathrm{~m}$ in the middle part, and $3.2 \mathrm{~m}$ in the lower part. The main scarp of the landslide as a result of headward erosion in that period receded $30 \mathrm{~m}$ (Fig. 5).

The clearly increased activity of the Central Landslide resulting from the creation of Włocławek Reservoir was maintained for 13 years, followed by a clear decrease in its dynamics. Between the mid-1980s and mid-2001, the movements reached only $1.0-1.7 \mathrm{~m} /$ year and were comparable with values recorded in the period before the reservoir was created. In 1983-2002, the upper edge of the landslide receded $12 \mathrm{~m}$ on average (Fig. 5).

However, from September 2001 till March 2002 (i.e. after nearly 20 years of dynamic balance of the Central Landslide), the rate of movements increased remarkably (Fig. 5). After that period, landslide activity returned to mean values. 
Between December 2002 and the autumn of 2008, the Central Landslide developed at a similar rate as before the damming of the river, i.e. 1-2 m/year. Again, signs of landslide acceleration (for the third time during the 40-year research on this form), were recorded in October 2008. The road on the landslide and the surface drainage network protection were moved 0.4-0.5 m. Till March 2009, the displacement reached $0.9 \mathrm{~m}$. In the following months, landslide activity increased. Total displacement during 10 months of highest landslide activity, i.e. from April 2010 till February 2011, reached 13.2-23.1 m, with largest movements from 20 January to 10 February 2011 (Fig. 5). These values are unusually high, never recorded during the earlier 40-year research on this form. On the landslide surface, numerous transverse ridges, scarps, cracks, and cavities were formed and quickly filled with water. The surface drainage network was completely destroyed. Its restoration was initiated as late as in 2014. Deformations affected the beach, paved footpath, and stone gabion protection of the bank, which was pushed into the reservoir by the pressing colluvial masses (Banach et al. 2013). Landslide morphology was remodelled completely. The cracks
Fig. 5 Dynamics of movements of the Central Landslide in relationship to precipitation and reservoir water level during the monitoring period, 1970-2011.

a Colluvium surface movements recorded at control points (benchmarks). Numbering of benchmarks compatible with Fig. 2. b Deviation (\%) from the long-term mean of annual precipitation. c Monthly reservoir water level fluctuations. d Monthly reservoir water amplitudes
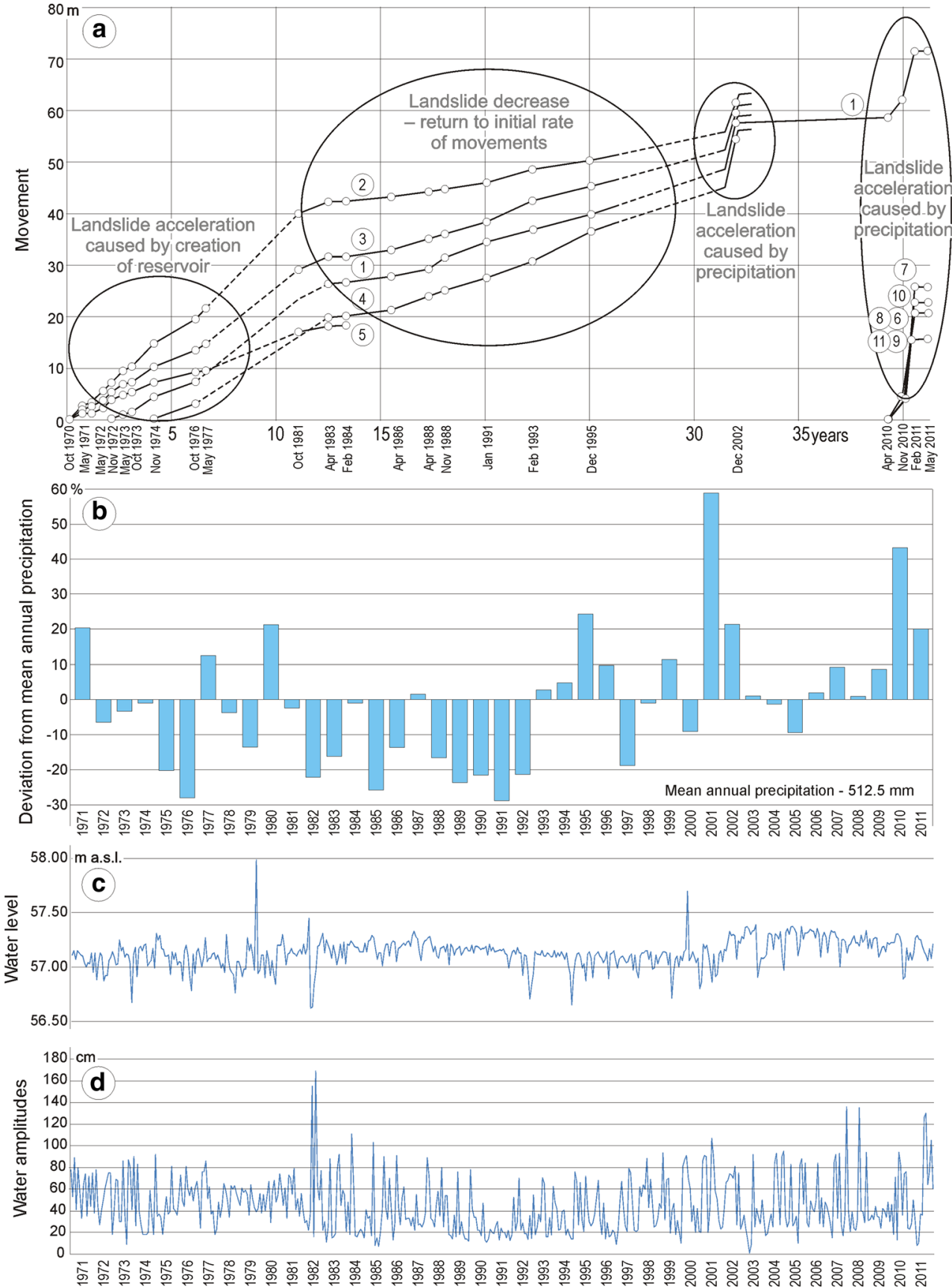
were deeper and broader, and many new depressions were formed and filled with water. Its toe entered the reservoir in a 60-m section of the shoreline, causing transformation of its bottom (Fig. 6). The main scarp between December 2010 and February 2011 receded 3-5 m (Fig. 7).

After that period of unusually intensive movement, the rate of landslide displacement returned to mean values. From February till November 2011, the highest values of current movements recorded in the middle part of the landslide reached on average $0.01-0.03 \mathrm{~m} / \mathrm{month}$.

On the basis of geotechnical research conducted in the late 2012, the factor of safety $F s$ was estimated (by the Bishop method, Kuszyk et al. 2012). It reached 1.43 along the main cross section of the landslide (Figs. 2, 3) and $\sim 1.2$ for the lower surface part of the landslide, where slow earthflow was observed.

\section{Discussion}

\section{Causes of periodical landslide acceleration on slopes of reservoirs and their relation to the Central Landslide}

During the last 40 years, 3 periods of increased landslide activity were observed at the study site. They varied in significance, duration, and causes. The first, longest period lasted from 1970 to 1983 . The next 2 periods, lasting several months each, occurred in 2001/2002 and 2010/2011 (Fig. 5). To explain the causes of periodical landslide acceleration, we analysed both natural and anthropogenic factors that could have affected the landslide: weather conditions, water level fluctuations in the reservoir, shoreline erosion intensity, and maintenance or repair operations in the reservoir and any engineering/technical activities in its immediate neighbourhood in the whole study period.

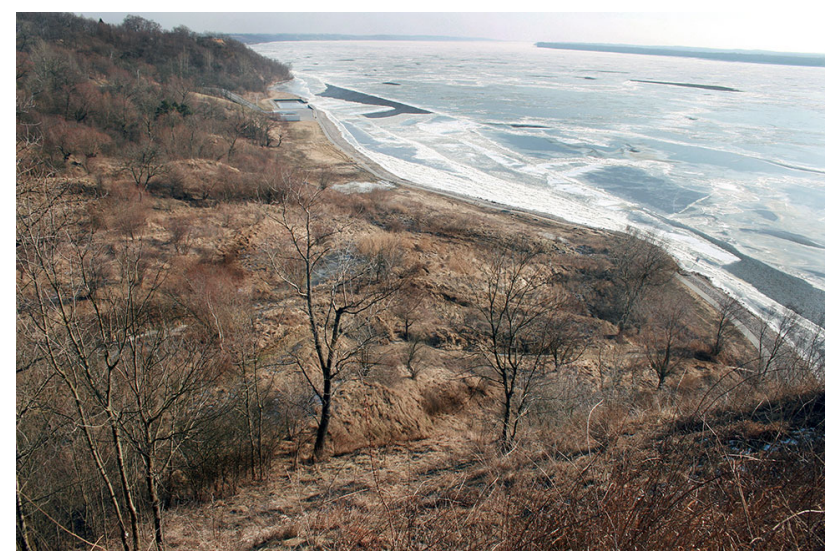

Fig. 6 Lower part of the Central Landslide

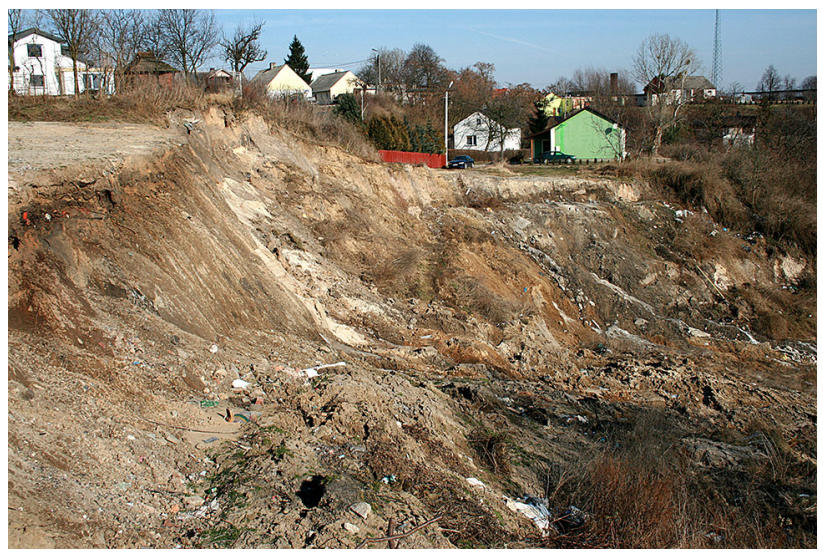

Fig. 7 The main scarp of the Central Landslide after acceleration in 2010-2011

One of the major hydrological causes of the periodical increase in the activity of deep landslides, such as the Central Landslide, is the increase in pore water pressure within the surface of rupture, caused by a rise in groundwater level (Van Asch et al. 1999) as a result of prolonged period of rainfall, frequently associated with snowmelt (Cruden et al. 1995; Prokesova et al. 2013). Deeper landslides need larger absolute amounts of water for triggering conditions than shallower landslides. These forms are reactivated when abnormally high precipitation continues over a long period, often lasting for several months to several years (e.g. Iverson and Major 1987; Cruden et al. 1995; Corominas and Moya 1999; Van Asch et al. 1999; Rybáŕ 2006; Gattinoni et al. 2012). Slightly above-average rainy season following the prolonged wet period can be far more responsible for movement acceleration (and possibly failure initiation) in deep landslides than the isolated season of extreme precipitation following a longer dry period (Prokesova et al. 2013).

Central Landslide acceleration, observed as late as 6 months after long-term heavy rainfall, indicates that precipitation (causing an increase in soil moisture content) is a very important factor enabling landslide acceleration, but the acceleration was triggered by an increased amount of water reaching the sliding zone. The shear strength of the sliding zone weakened gradually. Mean annual precipitation in the vicinity of the Central Landslide in 1970-2011 is $512.5 \mathrm{~mm}$ (62\% in May-October). The wettest month is July, with a mean precipitation of $72.8 \mathrm{~mm}$ ( $14 \%$ of annual precipitation), while the driest month is February, with a mean precipitation of $26.3 \mathrm{~mm}$ (only $5 \%$ of annual precipitation). During the 40 years, precipitation was average in most years, and only 2 years were distinguished by very high precipitation, $45 \%$ higher than the annual mean. These were the years 2001 and 2010, with unusually wet summers (Fig. 5), which were followed by increased landslide activity in winter. 
Changes in water level in reservoirs are frequently analysed as triggers of landslides located on slopes of these artificial water bodies. A higher than average, sudden decrease in water level in a water body results in a short-term increase in hydraulic gradient in adjacent slopes. Many times this factor was regarded as the major cause of creation or reactivation of landslides developed at the shores of reservoirs (Jones et al. 1961; Rybár 1974; Banach and Spanila 2000; Vichas et al. 2001; Schuster and Wieczorek 2002; Spanila et al. 2002; Deying et al. 2010; Pinyol et al. 2012). A positive correlation was noticed between landslide activity level and the magnitude of lowering of water level in the reservoir. For example, on Lake Roosevelt on the Columbia River in the USA, landslides are activated slightly if the fall is not larger than $9 \mathrm{~m}$, moderately if the fall amounts to $9-15 \mathrm{~m}$, and most strongly if the fall is larger than $15 \mathrm{~m}$ (Jones et al. 1961). To minimise the effect of this factor on landslide development, regulations are introduced to limit the rate of drawdowns. For Lake Roosevelt, the limits are: $0.46 \mathrm{~m}$ per $24 \mathrm{~h}$ or $0.91 \mathrm{~m}$ per $48 \mathrm{~h}$ (Riedel 1997), for Nechranice Reservoir (Czech Republic) $0.15 \mathrm{~m}$ per $24 \mathrm{~h}$, but less than $10 \mathrm{~m}$ in total (Spanila 1996), and similarly, $0.15 \mathrm{~m}$ per $24 \mathrm{~h}$ for Canelles Reservoir (Spain) (Pinyol et al. 2012). The decrease in water level, as a factor destabilising the slope, affects it very strongly but shortly: only at the time of the increased hydraulic gradient. Its effects are visible directly after or even during the hydrological event. This factor is significant in case of large drawdowns, when water level drops a few metres.

However, fluctuations of water level in Włocławek Reservoir are generally small. Annual mean water level in the whole period of its exploitation (1970-2011) varied from 57.02 (1972) to $57.30 \mathrm{~m}$ a.s.l. (2005). Daily fluctuations are generally small, irrespective of the season (mean $0.2 \mathrm{~m}$, range $0.1-0.4 \mathrm{~m}$ ). Monthly fluctuations rarely exceed $0.5 \mathrm{~m}$, exceptionally reaching up to $1.70 \mathrm{~m}$. Annual amplitudes of water level fluctuations only slightly exceed $1 \mathrm{~m}$, varying from $0.52 \mathrm{~m}$ in 1990 to $1.69 \mathrm{~m}$ in 1982. During emptying of the reservoir, before passage of a flood wave on the Vistula, water level changes exceed the mean of $0.2 \mathrm{~m}$ per $24 \mathrm{~h}$, but jointly they do not exceed $1 \mathrm{~m}$ in one episode.

Erosion of coastal slopes of artificial water bodies, particularly intensive in the initial period of their exploitation, is a commonly known factor lowering their stability (Banach 1985; Ovchinnikov et al. 1999). The process is gradually diminished as the resultant shore platform is developed and broadened at the slope base. Duration of intensive slope erosion depends on the magnitude of water level fluctuations in the reservoir and is extended as they increase. In water bodies with small fluctuations (about 0.5-1.5 m), including Włocławek Reservoir, the process lasts 15-25 years (Levkevic and Lopuch 2003; Banach
2004). When fluctuations are larger (several metres), stabilisation of the transformed slopes is prolonged or even questionable (Banach 2006; Kaczmarek 2010a, b; Kaczmarek and Tyszkowski 2009; Ovchinnikov et al. 1999).

The first, conspicuously nearly $40 \%$ increase in the rate of movements within the Central Landslide was recorded in the early 1970s and lasted till 1983 (Fig. 5). Those years were distinguished by average or slightly lower rainfall. Only in 1970, 1977, and 1980, annual precipitation slightly exceeded mean values for 1970-2011 (Fig. 5). The period of landslide acceleration coincided with the initial filling of the reservoir and the first years of its exploitation, so it was a direct effect of damming of the river. The $8-\mathrm{m}$ rise in water level, as compared to mean water level in the Vistula before its damming, caused a decrease in shear strength as a result of an increase in soil moisture content (reduced soil cohesion below the water level in the reservoir).

Simultaneously, slope angle increased due to its flooding followed by shoreline erosion caused by wind waves in the lower part, which earlier stabilised the whole slope. The intensity of slope erosion in the Central Landslide in the first years after damming of the Vistula was very high. In the first 4 years after creation of the reservoir (1971-1974), the river bank moved there about $5 \mathrm{~m}$ back, although the landslide toe at that time moved $15 \mathrm{~m}$ towards the Vistula. After creation of the reservoir, at the base of the slope, a shore platform started to develop in a natural way. It was initially narrow and steep, but in 1983 it was already $17-22 \mathrm{~m}$ wide in that area, while slope angle was $4^{\circ}-6^{\circ}$. This form markedly limited the effectiveness of slope erosion in the neighbouring parts of the shore, as it decreased from $2.3 \mathrm{~m} / \mathrm{year}$, in the first 6 years of exploitation of the reservoir, to $1.0 \mathrm{~m} /$ year after 12 years of its exploitation (Banach 1994). Intensification of mass movements within the slope of the Vistula valley in that period could be partly caused also by small (less than $1 \mathrm{~m}$ high) and short-term water level fluctuations in the reservoir, especially in the first years of its operation (Glazik 1978) (Fig. 5). However, they certainly were not the major reasons for the movements.

In 1983, i.e. 14 years after creation of Włocławek Reservoir, the rate of movements within the Central Landslide markedly declined, to the initial level before creation of the reservoir (1.0-1.7 m/year). The decrease in landslide activity observed till 2001, was partly caused by a further reduction of the intensity of slope damage by erosion, from about 1.0 to $0.5 \mathrm{~m}$ /year (Banach 1994), thanks to the broadening of the shore platform and very low precipitation (Fig. 5).

The second, minor, and short-term acceleration of the Central Landslide was observed between September 2001 and February 2002. The activation coincided with extremely high precipitation, the highest during the 40 years 
Fig. 8 Temperature and precipitation before and during landslide acceleration in 2010-2011

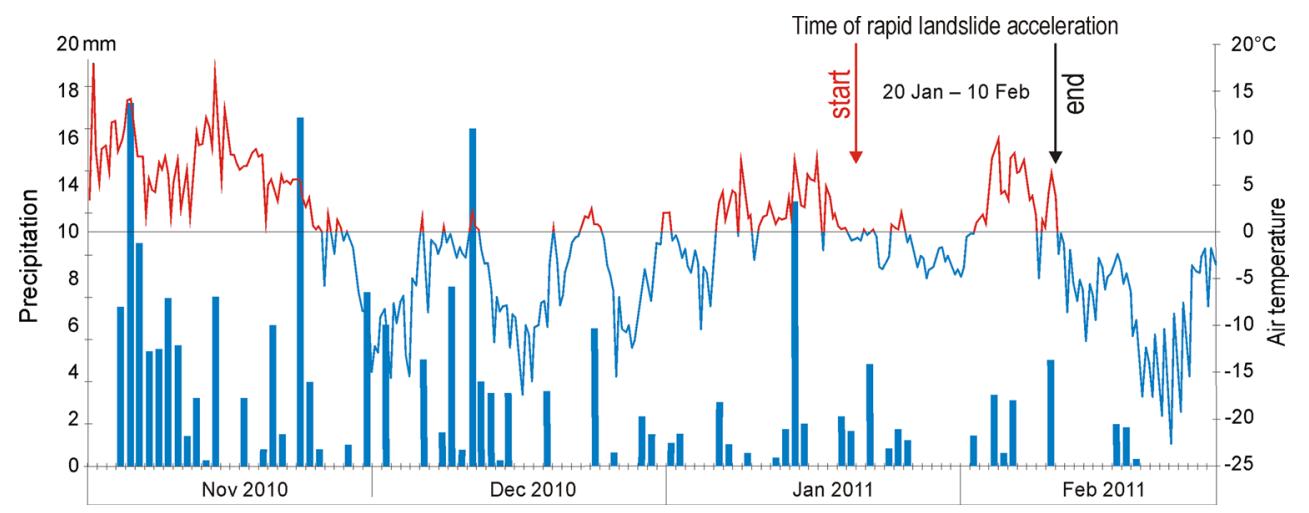

of observations. Annual precipitation in 2001 reached $826 \mathrm{~mm}$, so it was $61 \%$ higher than the mean for 1970-2010. This was due to heavy rainfall in spring and summer (April-September), when monthly precipitation was 68-227\% higher than the corresponding monthly means for 1970-2010. After a drier October and November 2001, the next few months were also extremely wet. Precipitation in February 2002 was $282 \%$ higher than the corresponding monthly mean for 1970-2010 and was the highest in the study period (Fig. 5).

In the period preceding landslide activation as well as during the activation, 2 unusually large drawdowns were recorded: in July and October 2001. In July, water level fell $0.65 \mathrm{~m}$ within 5 days, with a maximum rate of $0.35 \mathrm{~m} /$ day. In October, it fell $0.62 \mathrm{~m}$ within 7 days, with a maximum rate of $0.24 \mathrm{~m} /$ day. The fluctuations did not affect landslide morphology and increased its dynamics.

The third period of acceleration of the Central Landslide occurred in 2010/2011. Like previously, landslide activation lasted only a few months. However, the magnitude and rate of mass movements was most spectacular in the whole 40-year history of research on this form (Fig. 5).

While searching for causes of the increase in activity of the Central Landslide in 2010/2011, we analysed data on water level in Włocławek Reservoir in the period preceding the landslide acceleration. Mean water level in Włocławek Reservoir in 2010 was $57.15 \mathrm{~m}$ a.s.1. and varied from 56.01 to $57.39 \mathrm{~m}$ a.s.l. Annual variation reached $1.39 \mathrm{~m}$, so it was much higher than the long-term mean. Water level fluctuations particularly unfavourable for slope stability occurred in the reservoir in late May and early June of that year. Within $24 \mathrm{~h}$, on 20 May, water level in the reservoir increased as much as $0.65 \mathrm{~m}$, reaching $57.40 \mathrm{~m}$ a.s.l. and exceeding the maximum level by $0.10 \mathrm{~m}$. On the next day, 21 May, it decreased $1.04 \mathrm{~m}$, to $56.36 \mathrm{~m}$ a.s.l., and in the next few days, to $56.01 \mathrm{~m}$ a.s.l. The low water level (about $1 \mathrm{~m}$ lower than long-term average) lasted 25 days, until 15 June. These substantial and rapid changes in Włocławek Reservoir, however, did not influence the acceleration of the Central Landslide (Fig. 5).
The major reason for the disastrous movement of the Central Landslide in late January and early February 2011 was probably associated with the extremely unfavourable weather conditions in the months preceding it, and the resultant increased infiltration of the sliding surface (Fig. 8). After the years 2003-2009, when annual precipitation was close to the mean value for 1971-2010, the year 2010 was very wet. Annual precipitation then reached $744.7 \mathrm{~mm}$, so it was $45 \%$ higher than the long-term mean. It was the second wettest year in the whole 40-year period of research. Precipitation in the warm half-year (MayOctober 2010) reached $514 \mathrm{~mm}$, and was $63 \%$ higher than the long-term mean. A similar extremely high monthly precipitation was recorded in November $(115 \mathrm{~mm}$, i.e. $315 \%$ of the mean value for 1970-2011). The nearly 20-day-long rainfall, with little evaporation, facilitated water infiltration into fissured, loosened colluvium. In December 2010, precipitation of $61 \mathrm{~mm}$ was $57 \%$ higher than the long-term mean.

The unfavourable effect of precipitation on stability of the Central Landslide was aggravated by low air temperature. Since 26 November, air temperature for most of the day was below $0{ }^{\circ} \mathrm{C}$, water was retained in the soil and on the surface, as snow cover. Higher temperatures were recorded on 7-20 January (daily mean air temperature $-1.2-5.4^{\circ} \mathrm{C}$ ) and $4-11$ February $\left(-3.2-8.2{ }^{\circ} \mathrm{C}\right)$. The sudden warm spell, resulting in the release of groundwater and melting of the accumulated snow cover, caused greater hydration of colluvium, an increase in its weight, and lowering of shear strength (Fig. 8).

A situation similar to that on the Central Landslide in 2010/2011 was observed in Koronowo, located about $100 \mathrm{~km}$ NW of Dobrzyń (Zabuski et al. 2015). The landslide studied there has a similar geomorphological and geological setting like the Central Landslide. The landslide monitored there was substantially moved in early February 2011. The cited authors suggested that it was due to heavy rainfall and snowfall in November and December 2010, which corresponded to 134 and $255 \%$, respectively, of the 34-year mean for this region. Like in Dobrzyń, a warm 
spell took place there in mid-February and caused the snow to melt and release the water trapped in the slope.

However, the major factor enabling the strong influence of precipitation and snow melt on the development of the Central Landslide was its location within the axis of a Miocene syncline. The syncline performs the function of a local discharge area, where groundwater from neighbouring areas is collected. Groundwater, particularly after longterm and intensive rainfall and snowmelt, gradually infiltrate the sliding surface. This process, coinciding with a high moisture content of displaced material and its reduced shear strength resulted in the acceleration of the Central Landslide, on an exceptionally large scale between 20 January and 10 February 2011 (Fig. 5).

\section{Conclusions}

Central Landslide is an old, deep rotational landslide developed on a slope of a plateau, within a Miocene syncline playing a role of local discharge area. In 1969 the landslide was partly flooded because of creation of Włocławek Reservoir. Since 1969, in its dynamics, 3 periods of landslide acceleration can be distinguished, varying in scale and duration. The resultant hydrological and morphological changes at the shoreline on the slope, i.e. rise in water table, erosion of coastal slope led to a substantial and longterm (13 years) increase in dynamics of the Central Landslide, of nearly $40 \%$ in comparison to the preceding period. After that period, as a consequence of development of the shore platform, which is a natural barrier protecting the colluvium against damage by water, landslide activity clearly declined, to a level recorded before the damming of the river.

Landslides developed on slopes of reservoirs are particularly sensitive to hydrometeorological conditions both in their vicinity (i.e. unusually high, often long-lasting precipitation and snowmelt) and within the water body (i.e. sudden and severe decrease in water level, exceeding mean values for the given site). During 40 years of observations of the Central Landslide, its short-term activation was recorded twice: in 2001/2002 and 2010/2011. In both cases, landslide acceleration was preceded by unusually longlasting, heavy rainfall a few months earlier. It resulted in increased infiltration of the sliding surface by groundwater, due to the location of the Central Landslide within the syncline. The shear strength of the sliding zone was weakened gradually.

The most spectacular displacement within the Central Landslide was recorded between December 2010 and February 2011, reaching 10.0-19.4 $\mathrm{m}$. The unprecedented increase in the rate of movements of the Central Landslide most probably resulted from, unusually long-lasting, heavy rainfall in summer and autumn 2010, followed by snowmelt and unfavourable changes in air temperature in 2010/2011 and infiltration of the sliding surface with groundwater.

Our results of research of the Central Landslide confirm that in reservoirs with small water level fluctuations in the initial period of their functioning, landslide development is strongly related to shoreline erosion. In the later period, when the shore platform develops, hydrometeorological factors again become the major factors affecting landslide development.

Acknowledgments This study was partly supported by the Ministry of Science and Higher Education (Grants N N306 033033 in 2007-2009 and N N306 086037 in 2009-2012) and Virtual Institute of Integrated Climate and Landscape Evolution (ICLEA) of the Helmholtz Association. The manuscript was translated into English by Sylwia Ufnalska, MSc, MA.

Open Access This article is distributed under the terms of the Creative Commons Attribution 4.0 International License (http://creativecommons.org/licenses/by/4.0/), which permits unrestricted use, distribution, and reproduction in any medium, provided you give appropriate credit to the original author(s) and the source, provide a link to the Creative Commons license, and indicate if changes were made.

\section{References}

Alonso EE, Pinyol NM, Puzrin AM (2010) Catastrophic Slide: Vaiont Landslide, Italy. In: Alonso EE, Pinyol NM, Puzrin AM (eds) Geomechanics of Failures. Advanced Topics. Springer, Netherlands, pp 33-81. doi:10.1007/978-90-481-3538-7_2

Banach M (1977) Rozwój osuwisk na prawym zboczu doliny Wisły między Dobrzyniem a Włocławkiem (The growth of landslides of the right-bank slope of the Vistula Valley between Dobrzyn and Wloclawek). Pr Geogr IGiPZ PAN 124

Banach M (1985) Geodynamika zbocza doliny Wisły w Dobrzyniu (Geodynamics of the Vistula slope in Dobrzyń). Prz Geogr 57(4):527-551

Banach M (1994) Morfodynamika strefy brzegowej zbiornika Włocławek (Morphodynamics of the Włocławek Reservoir coastal zone). Pr Geogr IGiPZ PAN 161

Banach M (2004) Ewolucja strefy brzegowej zbiorników zaporowych (Evolution of water reservoirs shore zone). Dokumentacja Geogr $31: 11-12$

Banach M (2006) Changes in geomorphology of new shoreline after the filing of the Włocławek artificial Lake. Pr Geogr UJ 116:23-32

Banach M, Spanila T (2000) Geodynamic evolution of water reservoir banks. Acta Montana IRSM AS CR Ser A 15(116):45-66

Banach M, Kaczmarek H, Tyszkowski S (2013) Rozwój osuwisk w strefie brzegowej sztucznych zbiorników wodnych na przykładzie osuwiska centralnego w Dobrzyniu nad Wisłą, zbiornik włocławski (Development of landslides in the shore zones of reservoirs base Central Landslide in Dobrzyń, Włocławek Reservoir). Prz Geogr 85(3):397-415

Corominas J, Moya J (1999) Reconstructing recent landslide activity in relation to rainfall in the Llobregat River basin, Eastern Pyrenees, Spain. Geomorphology 30:79-93

Cruden DM, Thomson S, Kim HJ, Peterson AE (1995) The Edgerton landslides. Canadian Geotech J 32(6):989-1001. doi:10.1139/ t95-097 
Deng J, Wei J, Min H, Tham LG, Lee CF (2005) Response of an old landslide to reservoir filling: a case history. Sci China Ser E-Technol Sci 48(1):27-32. doi:10.1360/04zze3

Deying L, Kunlong Y, Chin L (2010) Analysis of Baishuihe landslide influenced by the effects of reservoir water and rainfall. Environ Earth Sci 60:677-687. doi:10.1007/s12665-009-0206-2

Du YL, Wang SJ, De B, Wang J (1996) Some landslides triggered typically by impounding of water reservoir in China. In: Proceedings of 7th Int Symp on landslides, Trondheim, Proc of 7th Int Symp on landslides, Trondheim, 17-21 June 1996, Norway

Fawu WF, Peng X, Zhang Y, Huo Z, Takeuchi A, Araiba K, Wang G (2006) Landslides and slope deformation caused by water impoundment in the Three Gorges Reservoir, China. IAEG Paper 137:1-13

Gattinoni P, Scesi L, Arieni L, Canavesi M (2012) The February 2010 large landslide at Maierato, Vibo Valentia, Southern Italy. Landslides 9(2):255-261. doi:10.1007/s10346-011-0296-2

Gelinek K (1929) Osuwiska nad Wisłą. Przyczynek do fizjografji wysokich brzegów nadwiślańskich (Landslides on Vistula River. The contribution for high Vistula River banks physiography). In: Pamiętnik Drugiego Zjazdu Geografów i Etnografów Słowiańskich w Polsce, Towarzystwo Naukowe w Płocku, Kraków, pp 212-215

Genevois R, Ghirotti M (2005) The 1963 Vaiont Landslide. G di Geol Appl 1:41-52. doi:10.1474/GGA.2005-01.0-05.0005

Gierszewski PJ, Szmańda JB (2010) Litodynamiczna interpretacja warunków akumulacji osadów dennych Zbiornika Włocławskiego (Lithodynamical interpretation of Włocławek reservoir bottom deposits sedimentological condition). In: Ciupa T, Suligowski R (eds) Woda w badaniach geograficznych. IG UJK, Kielce, pp 169-177

Glazik R (1978) Wpływ zbiornika wodnego na Wiśle we Włocławku na zmiany stosunków wodnych $\mathrm{w}$ dolinie (The effect of a reservoir on the Vistula near Włocławek of the hanges of aquatic conditions in the valley). Dokumentacja Geogr 2-3

He K, Li X, Yan X, Guo D (2008) The landslides in the Three Gorges Reservoir Region, China and the effects of water storage and rain on their stability. Environ Geol 55:55-63. doi:10.1007/s00254007-0964-7

Iverson RM, Major JJ (1987) Rainfall, groundwater flow, and seasonal movement at Minor Creek landslide, northwestern California: Physical interpretation of empirical relations. Geol Soc Am Bull 99:579-594

Jones FO, Embody DR, Peterson WL (1961) Landslides along the Columbia River Valley, Northeastern Washington. US Geological Survey Professional Paper 367

Kaczmarek H (2010a) Analiza zdjęć lotniczych oraz wyników pomiarów geodezyjnych w badaniach dynamiki strefy brzegowej sztucznych zbiorników wodnych-zbiornik Jeziorsko, rzeka Warta (Using of the aerial photogrammetry and terrain measuring in monitoring shore zone of Jeziorsko Reservoir-Warta river, Central Poland). Landf Anal 13:19-26

Kaczmarek H (2010b) Development of the shore zone of the Jeziorsko Reservoir (the Warta River, Central Poland). Geomorphol Slovaca et Bohem 1:16-24

Kaczmarek H, Tyszkowski S (2009) The use of the aerial ground photogrammetry in the Jeziorsko Reservoir shore zone monitoring (the Warta River, Central Poland). Geomorphol Slovaca et Bohem 2:7-12

Kuszyk R, Charczuk Ł, Juraś K, Ryndak U, Cała A, Godlewska-Słaby A, Pilipczuk A (2012) Dokumentacja geologiczno-inżynierska dla potrzeb stabilizacji skarpy wiślanej w Dobrzyniu nad Wisłą na $661 \mathrm{~km}$ Wisły przy jeziorze Włocławskim (Geological and engineering documentation for the stabilization of the Vistula River embankment in Dobrzy, $661 \mathrm{~km}$ of the Vistula River near the Lake Włoclawek). HydroGeoStudio, Warszawa (unpublished report)

Levkevic VE, Lopuh PS (2003) Conceptual and theoretical assumptions of the development of contemporary coastal processes on reservoirs of Belarus In: Theoretical and applied problems of contemporary limnology. Proc of Int Conference, 20-24 October 2003. Minsk, pp 111-121 (in Russian)

Loo H (2006) Reactivation of an old landslide in response to reservoir impoundment and fluctuations. Dissertation, University of Hong Kong

Madej J (1981) Obliczeniowa prognoza stateczności skarpy wiślanej w Dobrzyniu n/Wisłą (Computational prediction of slope stability Vistula River in Dobrzyń). Stateczność skarpy wiślanej i metody jej zabezpieczania. Towarzystwo Naukowe Płockie, Płock, pp 83-96

Meissner K (1970) Własności inżyniersko-geologicznne iłów poznańskich rejonu Konina (The geological-engineering properties of Posnanian clays of Konin area). Biuletyn IG 231:114-187

Nazarov NN (2008) Geodynamical processes on coastal zone of Perm Region reservoirs. Izdatelstvo Poligrafkomplekt, Perm, USSR (in Russian)

Ostaficzuk S (1998) Tło neotektoniczne Skarpy Płockiej (Neotectonic background Płock scarp). In: Wysokiński L (ed) Przemieszczenia Skarpy Płockiej-konferencja naukowo-techniczna, Płock, 22 maja 1998 r. Instytut Techniki Budowlanej, Warszawa, pp 81-94

Ovchinnikov GI, Trzhtsinsky JB, Pavlov SH (1999) Changes of geological environment in zones of influencing of AngaroJenisej Cascade Reservoirs. Izdatelstvo Nauka, Novosibirsk (in Russian)

Panizzo A, De Girolamo P, Di Risio M, Maistri A, Pataccia A (2005) Great landslide events in Italian artificial reservoirs. Nat Hazards Earth Syst Sci 5:733-740. doi:10.5194/nhess-5-733-2005

Pinyol N, Alonso E, Corominas J, Moya J (2012) Canelles landslide: modelling rapid drawdown and fast potential sliding. Landslides 9:33-51. doi:10.1007/s10346-011-0264-x

Prokešová R, Medved'ová A, Tábořík P, Snopková Z (2013) Towards hydrological triggering mechanisms of large deep-seated landslides. Landslides 10(3):239-254. doi:10.1007/s10346-0120330-z

Reservoir Landslides: Investigation and Management: Guidelines and Case Histories (2002) International Committee on Large Dam (ICOLD), Commission Internationale des Grands Barrages, Paris

Riedel JL (1997) Lake Roosevelt National Recreation Area. Water Resources Scoping Report, National Park Service, Department of the Interior, Fort Collins, Denver

Riemer W (1995) Landslides and reservoirs. In: Bell DH (ed) Proc 6th Int Symp on Landslides, 10-14 February 1992, Christchurch, 3, Additional papers, reports, discussion, International Association of Engineering Geology. Balkema Publishers, Rotterdam, pp 213-224

Rybáŕ J (1974) Prediction of slope failure on water reservoir banks. Bull IAEG Kref 16:64-67. doi:10.1007/BF02591449

Rybár J (2006) Climatic effects in the development of different types of slope movements, Zprávy Geologického Výzkumu, pp 90-92

Schuster RL (1979) Reservoir induced landslides. Bull Int Assoc Eng Geol 20:8-15. doi:10.1007/bf02591233

Schuster RL, Wieczorek GF (2002) Landslide tiggers and types. In: Rybář J, Stemberk J, Wagner P (eds) Proc of 1st European Conference on Landslides, Prague, Czech Republic, Balkema Publishers, Taylor \& Francis, Prague, pp 59-78

Spanila T (1996) Landslides and abrasion processes on the shoreline of water reservoir. In: Senneset K (ed) Landslides. Balkema, Rotterdam, pp 579-583

Spanila T, Horsky O, Banach M (2002) Slides and sliding in the waters reservoirs banks. Proc of 1st European Conference on 
Landslides, Prague, Czech Republic, June 24-26. Balkema Publishers, Taylor \& Francis, Prague, pp 315-319

Trzhtsinsky JB, Demianovic NI (1977) Landslides of Angara River Reservoirs. In: Study of costal zone of Siberian Reservoirs, Nauka, Sibirijskoje Otdielienie, Novosibirsk, pp 97-117 (in Russian)

Tyszkowski S (2012) Rekonstrukcja dynamiki oraz próba określenia czynników inicjujących ruchy osuwiskowe we Wiągu (dolina dolnej Wisły) (Reconstruction of the dynamics and seek to identify factors which initiate landslide movement in Wiąg (lower valley of the Vistula River). Prace i Studia Geograficzne WGiSR UW 49:211-219

Van Asch TWJ, Buma J, Van Beek LPH (1999) A view on some hydrological triggering systems in landslides. Geomorphology 30(1-2):25-32. doi:10.1016/S0169-555X(99)00042-2

Vichas C, Skourtis C, Stiros S (2001) Kinematics of a landslide over The Polyphyton Reservoir (Greece). In: Procceedings of 10th Int Symp of Deformation Measurements, Int Federation of Surveyors, Orange, 19-22 March 2001, California. pp 71-77

Wang FW, Zhang YM, Huo ZT, Matsumoto T, Huang BL (2004) The July 14, 2003 Qianjiangping landslide, Three Gorges Reservoir, China. Landslide 1(2):157-162. doi:10.1007/s10346-004-0020-6

Wang FW, Wang G, Sassa K, Takeuchi A, Araiba K, Zhang Y, Peng Z (2005) Displacement monitoring and physical exploration on the shuping landslide reactivated by impoundment of the Three Gorges Reservoir, China. In: Sassa K, Fukuoka H, Wang FW, Wang G (eds) Landslides. Risk Analysis and Sustainable Disaster Management, Proc of Fourth ICL Symposium, Washington. pp 313-319. doi: 10.1007/3-540-28680-2_40

Wysokiński L (2006) Ocena stateczności skarp i zboczy (Evaluation of slope stability). Instrukcje, Wytyczne, Poradniki 424, Instytut Techniki Budowlanej, Warszawa

Xue G, Xu F, Wu Y, Yu Y (2009) Bank Slope Stability Evaluation for the Purpose of Three Georges Dam Construction. In: Wang F, Li $\mathrm{T}$ (eds) Landslide Disaster Mitigation in Three Georges Reservoir. vol Environmental Science and Engineering. Springer, Berlin, pp 41-86. doi:10.1007/978-3-642-00132-1_2

Zabuski L, Świdziński W, Kulczykowski M, Mrozek T, Laskowicz I (2015) Monitoring of landslides in the Brda river valley in Koronowo (Polish Lowlands). Environ Earth Sci :1-11. doi:10. 1007/s12665-015-4025-3

Zhang T, Yan E, Cheng J, Zheng Y (2010) Mechanism of reservoir water in the deformation of Hefeng landslide. J Earth Sci 21(6):870-875. doi:10.1007/s12583-010-0139-4 